\title{
Al-Qur'an Murottal Therapy to Reduce Cardiovascular Reactivity to Handgrip in Hypertensive Pre-Elderly Subjects
}

\author{
Elly Trisnawati ${ }^{1, *}$ I'anah Al Azizah $^{2}$ Ikhlas Muhammad Jenie ${ }^{3}$
}

\begin{abstract}
${ }^{1}$ Master of Nursing, Post Graduate Study, Universitas Muhammadiyah Yogyakarta, Yogyakarta, Indonesia ${ }^{2}$ Master of Nursing, Post Graduate Study, Universitas Muhammadiyah Yogyakarta, Yogyakarta, Indonesia ${ }^{3}$ Master of Nursing, Post Graduate Study, Universitas Muhammadiyah Yogyakarta, Yogyakarta, Indonesia *Corresponding author.email: ellytrisnawati16@yahoo.com
\end{abstract}

\begin{abstract}
Cardiovascular reactivity is a response of the cardiovascular system when it reacts to physical stress or psychological stress that can affect hemodynamics. Murottal therapy as a complementary treatment to lower high blood pressure and it is an efficient therapy that can be easily done by every individual. This study aimed to determine the effectiveness of Al-Qur'an murottal therapy in reducing cardiovascular reactivity to handgrip in hypertensive pre-elderly. The study used a quasi-experimental nonequivalent control group pretest-posttest design. The sampling technique was non-probability(non-random) sampling with a quota sampling technique of 60 hypertensive pre-elderly grouped non-randomly $(\mathrm{n}=30)$ into the intervention group (odd number), and $(\mathrm{n}=30)$ the control group. The research subjects were given an isometric handgrip test for 3 minutes and measured after a 5-minute rest period, then given Al-Qur'an (Surah Ar-Rahman) Murrotal therapy for 15 minutes for 3 consecutive days and evaluated on day 3 on the BP variable, pulse, and MAP with digital tensimeter. Data were analyzed using an Independent T-Test. The results showed that the response in the form of increased systolic blood pressure was significantly higher for posthandgrip cardiovascular reactivity ( $\mathrm{p}$-value $<0.05$ ). The group that was given Al-Qur'an murottal therapy showed a significant positive response in the form of a decrease in systolic blood pressure (delta-12.97 $\pm 8.34 \mathrm{~mm} \mathrm{Hg}$; p-value $=0.000$ ), diastolic blood pressure (delta -7.07. $\pm 6.85 \mathrm{~mm} \mathrm{Hg}$; p-value $=0.000$ ), and MAP (delta $-9.26 \pm 5.81$; p-value $=0.000$ ) on cardiovascular reactivity but not on pulse ( $\mathrm{p}$-value> 0.05). This study concluded Al-Qur'an murottal therapy can reduce blood pressure reactivity, but does not affect pulse reactivity, through handgrip isometric exercises.
\end{abstract}

Keywords: Al-Qur'an Murottal therapy, hypertensive pre-elderly, cardiovascular reactivity, handgrip

\section{INTRODUCTION}

Hypertension is a major risk factor for cardiovascular disease and stroke[1]. Approximately 1.13 billion people in the world suffer from hypertension and every year there are 9.4 million people worldwide die caused by hypertension and complications of hypertension[2].

The prevalence of hypertension in Indonesia by age group is as follows: 18-24 years (13.2\%), 25-34 years $(20.1 \%), 35-44$ years $(31.6 \%), 45-54$ years $(45 \%), 55-64$ years $(52.2 \%)$, $65-74$ years $(63.2 \%)$, and 75 years $(69.5 \%)[3]$. This shows that hypertension increases from pre-elderly to elderly. An increase in the elderly population in Indonesia can also cause problems related to medical, psychological, economic, and social aspects, thus requiring efforts to improve the health of the elderly which need to be given starting from the pre-elderly age group (aged 45-59 years) [4].
Treatment of hypertension can be done using pharmacological and non-pharmacological treatments. However, long-term pharmacological treatment has side effects such as drug resistance and drug-related problems that can cause organ damage[5]. Therefore, more effective and safer treatment options are needed for hypertensive patients.

Murottal therapy is spiritual healing that can be done as a complementary treatment that is efficient and easy to apply for every individual. Al-Qur'an murottal therapy has elements of meditation, autosuggestion, and relaxation which will lead to calm and positive emotional responses which are very influential in generating positive perceptions and have an effect on blood pressure[6-8].

Cardiovascular reactivity is a response of the cardiovascular system when it reacts to physical stress or psychological stress that can cause physiological stimuli such as increased blood pressure, heart rate, and other hemodynamics[9]. Although still not popular clinically, cardiovascular reactivity can be used as a noninvasive 
method to identify the pre-clinical state of cardiovascular disease, i.e. pathogenic changes in cardiovascular structure and function, if continued, will manifest as cardiovascular diseases, such as hypertension, myocardial infarction, and stroke[10].

Excessive cardiovascular reactivity can be regarded as a predictor of the risk of cardiovascular disease as well as a prognosis of a high risk of death from heart failure in the future[11-12]. In hypertensive patients who have abnormal blood pressure levels, it is possible to have a high cardiovascular reactivity which can be used to predict the risk of complications from hypertensive diseases such as stroke in the future if they are not treated properly.

This study aimed to determine the effectiveness of AlQur'an murottal therapy in reducing cardiovascular reactivity to handgrip in hypertensive pre-elderly subjects.

This study aimed to determine the effectiveness of AlQur'an murottal therapy in reducing cardiovascular reactivity to handgrip in hypertensive pre-elderly subjects.

\section{METHOD}

\subsection{Research Design}

The design of this study was quasi-experimental with a pretest - posttest design to examine the effect of Al-Qur'an murottal therapy intervention on blood pressure response, pulse rate, and MAP in a pre-elderly group who did handgrip exercises.

\subsubsection{Population, Sample, and Sampling Technique}

The population in this study consisted of hypertensive pre-elderly subjects in Pedukuhan Karet, Pleret, Bantul, Yogyakarta according to inclusion and exclusion criteria.

The inclusion criteria in this study were: being preelderly aged 45-59 years with stage 1 to stage 2 blood pressure (categories based on AHA, 2017); including both male and female; having a history of taking hypertension drugs, willing to be the subjects of the research and fill in an informed consent. The exclusion criteria in this study were pre-elderly who had complications other than hypertension (such as stroke, diabetes mellitus, kidney failure), and patients with hearing loss (deaf).

Ethics of this research approved by the ethics commission of Universitas Aisyiyah Yogyakarta (UNISA) No.1294/KEP-UNISA/IX /2019.

The sampling technique used non-probability (nonrandom) sampling with a quota sampling technique of 60 hypertensive pre-elderly subjects divided into two groups non-randomly, namely 30 people in the intervention group (odd number), and 30 people in the control group (even number).

\subsubsection{Data Collection Tools (Instruments)}

i.Digital Tensimeter (Jumper, China)

This tool was used to measure blood pressure, pulse.

Calibration test number I-09.014-19120300199A.

\section{ii.Electronic Hand Dynamometer (Camry, USA)}

This tool was used to test cardiovascular reactivity with handgrip isometric exercises.

\section{iii.Earphones \& MP3}

This tool was used to listen to the murottal Al-Qur'an.

\section{iv.Timer / Stopwatch}

This tool was used to calculate the time when research subjects listen to the murottal Al-Qur'an for 15 minutes or perform a cardiovascular reactivity test for 3 minutes.

\section{v.Observation Sheet}

This tool was used to record the characteristics of research subjects and the results of measurements of blood pressure, pulse, and mean arterial pressure before and after intervention.

\subsection{Research Flow}

The intervention group and the control group were given 3 measurements, namely the pretest baseline, post test 1 , and post test 2 on the variables of blood pressure, pulse rate, and mean arterial pressure.

The intervention group and the control group were given an isometric handgrip test for 3 minutes, followed by measurements (post test 1) after a 5-minute break from the handgrip exercise period. In addition, the intervention group was given Al-Qur'an (Surah Ar-Rahman) murottal therapy which was played using earphones for 15 minutes; this therapy was carried out in the afternoon at 15.00 or after Azhar prayer for 3 consecutive days. On the other hand, those in the control group were not given the therapy; they were allowed to go home and carry out their daily activities as usual. The post test 2 measurements in both groups were carried out on day 3 .

\subsection{Isometric Handgrip Exercise}

The research subjects held a handgrip dynamometer with their dominant hand as hard as possible for 3 times and the total results of the 3 experiments were divided by three to determine the strength value. After that, they were asked to perform isometric contraction (holding handgrip 30\% of grip strength) with dominant hand for 3 minutes.

Then the research subjects released their grips and rested for 5 minutes before measured (post test 1). 


\subsection{Al-Qur'an Murottal Therapy}

The research subjects were instructed to sit and relax in a quiet environment (no noise), then listen to Al-Qur'an (Surat Ar-Rahman) murottal solemnly using earphones for 15 minutes for 3 consecutive days.

\subsection{Cardiovascular Reactivity Measurement Parameters}

\subsubsection{Blood pressure}

Systolic blood pressure, diastolic blood pressure, and mean arterial pressure were the parameters for measuring cardiovascular reactivity in this study by comparing the delta (difference) between the post-handgrip values after Al-Qur'an murottal intervention with the baseline values, post-handgrip before Al-Quran murottal intervention.

\subsubsection{Delta value of blood pressure}

Delta value of blood pressure was calculated from the posttest value post handgrip after the Al-Qur'an murottal intervention minus the pretest baseline value, and posthandgrip before the Al-Qur'an murottal intervention.

\subsubsection{Pulse rate}

Pulse rate is a measurement parameter for cardiovascular reactivity, and the pulse rate in this study was measured using a digital tensimeter which can also measure pulse rate.
The parameters for measuring cardiovascular reactivity in this study were by comparing the delta (difference) between the post-handgrip values after the Al-Qur'an murottal intervention with the baseline, pulse, posthandgrip values before the Al-Qur'an murottal intervention.

\subsubsection{Delta value of pulse rate}

Delta value of pulse rate was calculated from the post test value post-handgrip pulse rate after the Al-Qur'an murottal intervention minus the pretest baseline pulse rate, and the post-handgrip pulse rate before the Al-Qur'an murottal intervention.

\subsection{Statistic Analysis}

The statistical program used was SPSS version 21. The bivariate test used in this study was the Independent T-Test to see the differences in systolic blood pressure, diastolic blood pressure, pulse, and mean arterial pressure after intervention between the two groups. The difference was significant if the $\mathrm{p}$ value $<0.05$.

\section{RESULTS}

This study analyzed the effect of Al-Qur'an murottal therapy on systolic blood pressure, diastolic blood pressure, pulse, and mean arterial pressure in hypertensive preelderly in Pedukuhan Karet, Pleret, Bantul, Yogyakarta to find out whether Al-Qur'an murottal can decrease cardiovascular reactivity to handgrip in hypertensive preelderly subjects.

Table 1. Frequency Distribution Of Respondents By Age, Gender, History Of Hypertension, Physical Activity, Favorite Foods, And Cigarette Consumption In Intervention Groups

\begin{tabular}{|c|c|c|c|c|c|c|c|}
\hline \multirow{3}{*}{ Characteristics $(n=60)$} & \multicolumn{6}{|c|}{ Group } & \multirow[b]{3}{*}{ P-Value } \\
\hline & \multicolumn{3}{|c|}{ Intervention } & \multicolumn{3}{|c|}{ Control } & \\
\hline & Mean \pm SD & $\mathbf{F}$ & $\%$ & Mean \pm SD & $\mathbf{F}$ & $\%$ & \\
\hline Age (Yr) & $54 \pm 3,9$ & & & $54 \pm 4,3$ & & & 0,829 \\
\hline \multicolumn{8}{|l|}{ Gender } \\
\hline Female & & 17 & 57 & & 17 & 57 & \\
\hline Male & & 13 & 43 & & 13 & 43 & 1,000 \\
\hline \multicolumn{8}{|l|}{ History of Hypertension } \\
\hline Yes & & 18 & 60 & & 20 & 67 & \\
\hline Not & & 12 & 40 & & 10 & 33 & 0,595 \\
\hline \multicolumn{8}{|l|}{ Physical Activity } \\
\hline Routine & & 9 & 30 & & 9 & 30 & \\
\hline Rarely & & 7 & 23 & & 10 & 33 & \\
\hline Never & & 14 & 47 & & 11 & 37 & 0,619 \\
\hline \multicolumn{8}{|l|}{ Favorite Foods } \\
\hline Salty food & & 16 & 53 & & 22 & 73 & \\
\hline Sweet Food & & 14 & 47 & & 8 & 27 & 0,097 \\
\hline \multicolumn{8}{|l|}{ Cigarette consumption } \\
\hline Yes & & 11 & 37 & & 6 & 20 & \\
\hline Not & & 19 & 63 & & 24 & 80 & 0,155 \\
\hline
\end{tabular}


Based on Table 1, it is known that in this study all the characteristics of the research subjects in the two groups were comparable. This is based on the results of statistical tests on each characteristic variable with a p-value greater than> 0.05, which means that there is no difference between the characteristics of the intervention group and the control group.

Table 2. Frequency Distribution of Blood Pressure, Pulse, and Map of Research Subjects Before and After Intervention in The Intervention and Control Group

\begin{tabular}{|c|c|c|c|c|c|c|}
\hline \multirow{3}{*}{ Variable } & \multicolumn{6}{|c|}{ Group } \\
\hline & \multicolumn{2}{|c|}{ Intervention } & \multicolumn{4}{|c|}{ Control } \\
\hline & Mean \pm SD & Min & Max & Mean \pm SD & Min & Max \\
\hline \multicolumn{7}{|l|}{ Baseline } \\
\hline Systolic BP (mm Hg) & $145 \pm 13$ & 130 & 180 & $148 \pm 17$ & 130 & 200 \\
\hline Diastolic BP (mm Hg) & $90 \pm 9$ & 74 & 117 & $90 \pm 11$ & 70 & 128 \\
\hline Pulse (x/mnt) & $83 \pm 7$ & 70 & 100 & $83 \pm 9$ & 65 & 101 \\
\hline MAP (mm Hg) & $108 \pm 10$ & 94 & 133 & $110 \pm 12$ & 90 & 141 \\
\hline \multicolumn{7}{|c|}{$\begin{array}{l}\text { Post Handgrip before Murottal Al-Qur'an } \\
\text { Intervention }\end{array}$} \\
\hline Systolic BP (mm Hg) & $153 \pm 13$ & 130 & 191 & $151 \pm 21$ & 123 & 210 \\
\hline Diastolic BP (mm Hg) & $91 \pm 8$ & 75 & 111 & $91 \pm 11$ & 70 & 128 \\
\hline Pulse (x/mnt) & $83 \pm 8$ & 65 & 100 & $83 \pm 9$ & 68 & 100 \\
\hline MAP $(\mathrm{mm} \mathrm{Hg})$ & $111 \pm 8$ & 93 & 130 & $111 \pm 12$ & 93 & 142 \\
\hline \multicolumn{7}{|c|}{$\begin{array}{l}\text { Post Handgrip After Murottal Al-Qur'an } \\
\text { Intervention }\end{array}$} \\
\hline Systolic BP (mm Hg) & $132 \pm 12$ & 110 & 157 & $152 \pm 19$ & 110 & 200 \\
\hline Diastolic BP (mm Hg) & $82 \pm 9$ & 70 & 100 & $91 \pm 10$ & 75 & 123 \\
\hline Pulse (x/mnt) & $80 \pm 6$ & 70 & 94 & $81 \pm 8$ & 68 & 102 \\
\hline MAP $(\mathrm{mm} \mathrm{Hg})$ & $99 \pm 10$ & 83 & 117 & $111 \pm 11$ & 91 & 139 \\
\hline
\end{tabular}

Based on Table 2, it is known that the mean values of systolic blood pressure, diastolic blood pressure, and MAP in the intervention group and the control group increased significantly after being given a cardiovascular reactivity test to isometric handgrip.
Post-handgrip systolic blood pressure, diastolic blood pressure, and MAP responses after Al-Qur'an murottal intervention in the intervention group given Al-Qur'an murottal therapy were significantly lower than the control group (systolic BP $132 \pm 12$ vs $152 \pm 19$; Diastolic BP $82 \pm$ 9 vs $91 \pm 10 ;$ MAP $99 \pm 10$ vs $111 \pm 11$ ).

Table 3. The Average Value of Difference in Blood Pressure, Pulse, And Map Before And After Intervention in Control And Intervention Groups

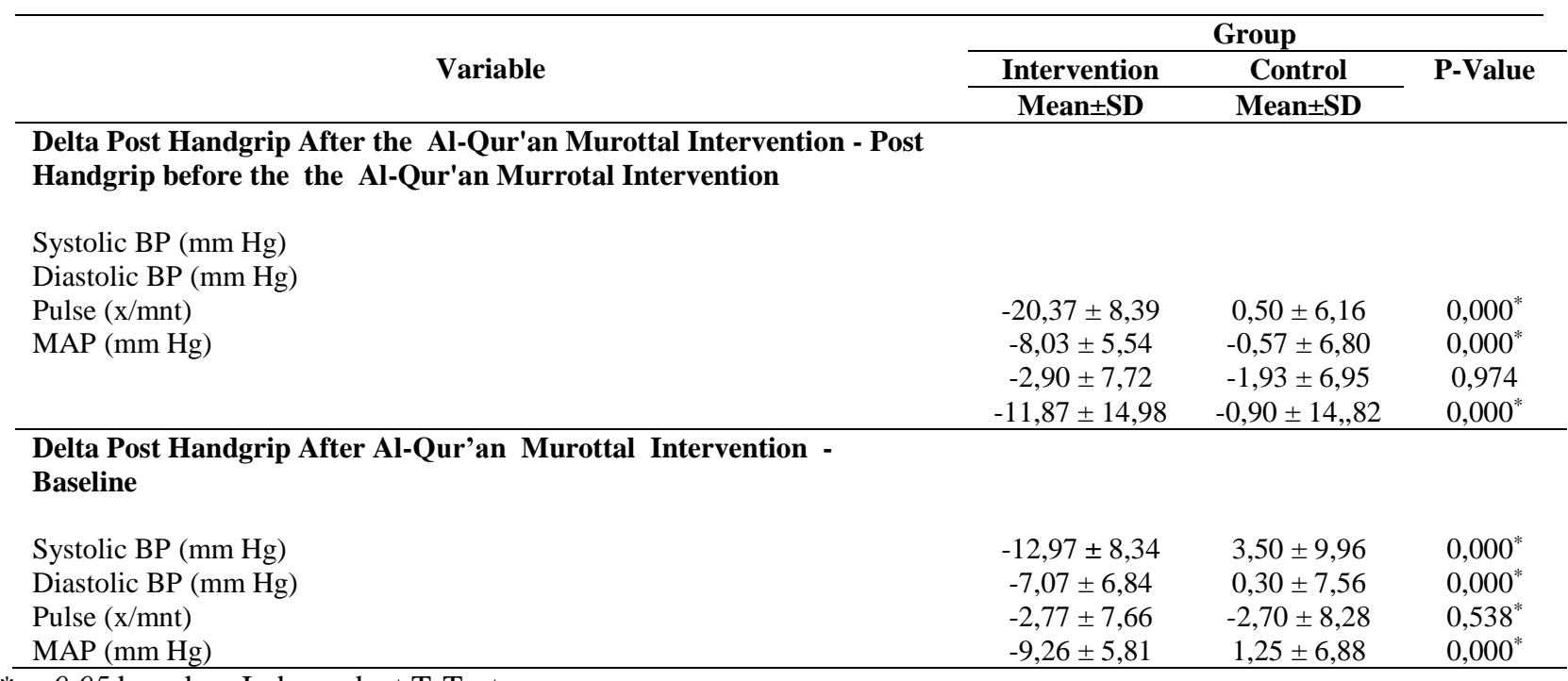

$* p<0,05$ based on Independent T-Test 
Based on Table 3, it is known that in the intervention group there was a significant difference in the post-handgrip systolic blood pressure, diastolic blood pressure, and MAP after the intervention of the Al-Qur'an murottal with those before the intervention of the Al-Qur'an murottal. Thus, it can be concluded that there was a positive response in the form of a decrease in the systolic blood pressure, diastolic blood pressure, pulse and MAP with a significant difference in mean in the group given the Al-Qur'an murottal intervention compared to the control group that was not given the Al-Qur'an murottal intervention.

The systolic blood pressure, diastolic blood pressure, and MAP in the intervention group decreased with a significant difference between the post-handgrip after given the Al-Qur'an murottal intervention and the baseline, whereas those in the control group experienced an increase with a mean difference.

Therefore, it can be concluded that performing AlQur'an murottal therapy for 3 days can significantly reduce systolic blood pressure ( $\mathrm{p}$-value $=0.000$ ), diastolic blood pressure $(\mathrm{p}$-value $=0.000)$, and MAP $(\mathrm{p}$-value $=0.000)$, but the Al-Qur'an murottal intervention statistically had no effect on lowering pulse rate with a p-value> 0.05 .

\section{DISCUSSION}

Al-Qur'an murottal therapy given for 3 days in hypertensive pre-elderly subjects had a positive response in reducing cardiovascular reactivity to handgrip, but AlQur'an murottal intervention did not statistically affect pulse rate.

The results of the research are in line with the results of a research by Irmachatshalihah and Armiyati, (2019) which showed that giving Al-Qur'an (Surah Al-Kahfi) murottal therapy for one day with a duration of 31 minutes 26 seconds is effective in reducing blood pressure and mean arterial pressure.

A research conducted by Nasiri et al., (2017) showed that Al-Qur'an murottal therapy given for 10 consecutive days with a duration of 15 minutes has a positive effect on vital sign value and GCS value.

However, the results of this study are different from the results of a research conducted by Ariyadi et al., (2018), showing that there is no effect of religious audio therapy on the hemodynamic status (blood pressure, pulse, MAP, respiration, SPO2) in stroke patients with decreased consciousness.

The researchers analyzed the factors for the difference in the results between a research conducted by Ariyadi et al., (2018) and the results in this study and concluded the factors to bethe time given and the conditions of the research subjects. In this study, the researchers provided audio Al-Qur'an (Surah Ar-Rahman) murottal therapy for 3 consecutive days with a listening duration of 15 minutes for pre-elderly with hypertension, while in Ariyadi's study, the therapy was administered twice a day for 2 days with a listening duration of 30 minutes in stroke patients with decreased consciousness.

Positive perceptions obtained from murottal will stimulate the hypothalamus to release endorphin hormones[13]. This hormone will make a person feel happy. Furthermore, the amygdala will stimulate the activation and control of autonomic nerves consisting of sympathetic and parasympathetic nerves. The parasympathetic nerves function to innervate the heart and slow down the heart rate, while the sympathetic nerves work the other way around. Controlled autonomic nerve stimulation will cause the secretion of epinephrine and norepinephrine by the adrenal medulla. Control of the epinephrine and norepinephrine hormones will inhibit the formation of angiotensin which can then lower blood pressure[13].

The results of this study indicated that the research subjects who received interventions to listen to the Qur'anic verses (murottal) had a good response in the form of a lowered blood pressure and MAP. The Al-Qur'an murottal provides positive energy, including from a psychological side, which can affect the body's chemical system which affects blood pressure as a response to internal and external environmental conditions that are considered to be the cause of health problems in a person[14]

The Al-Qur'an murottal provides positive energy which stimulates the auditory organs and limbic system. The hypothalamus stimulates the release of brain waves (alpha)[15-16]. These brain waves (alpha) cause the release of the neurotransmitter serotonin and endorphins. Both of these chemical substances will stimulate the parasympathetic nervous system which opposes the work of the sympathetic nervous system from cardiovascular reactivity in the isometric handgrip test, changing the cardiovascular system such as vasodilation of blood vessels and a decrease in Cardiac Output (CO), followed by a decreasein blood pressure.

In this study, Al-Qur'an murottal therapy had no effect on reducing pulse rate. This can occur because the pulse rate and blood pressure do not always correlate with the same rate or compensate for decreased blood pressure.

\section{LIMITATION}

The researchers did not control any possible bias factors that could affect blood pressure, pulse rate, MAP after the intervention, for example the food consumed by the study subjects during the intervention.

\section{CONCLUSION}

Al-Qur'an murottal therapy can reduce blood pressure reactivity, but does not affect pulse reactivity, through handgrip isometric exercises.

In nursing practices, Al-Qur'an murottal therapy as an effective intervention can be part of a care plan for patients, and it can be used as a non-pharmacological treatment (complementary therapy) to help lower blood pressure. 


\section{ACKNOWLEDGMENTS}

The researchers thank the Ministry of Education and Culture of the Republic of Indonesia for funding the postgraduate research grant for fiscal year 2020.

\section{REFERENCES}

[1] Feigin VL, Roth GA, Naghavi M, Parmar P, Krishnamurthi R, Forouzanfar $\mathrm{MH}$, Chugh S, , Mensah GA, Murray CJL, Norrving B, Shiue I, Ng M, Estep K., 2016. Global Burden Of Stroke And Risk Factors In 188 Countries, During 1990-2013: A Systematic Analysis For The Global Burden Of Disease Study 2013. Lancet Neurol Epub 2016 Jun 9 5(9):913-924. $\quad$ https://doi.org/10.1016/S14744422(16)30073-4

[2] World Health Organisation. 2013. A Global Brief on Hypertension Silent Killer Global Public Health Crisis. http://:www.who.int. Diakses pada 26 Juli 2019.

[3] RIKESDAS. 2018. Riset kesehatan dasar. Jakarta: Badan Penelitian Pengembangan Kesehatan Kementrian Kesehatan RI Kemenkes RI., 2013.

[4] Pusat Data dan Informasi Hipertensi. Jakarta: Balitbang Kemenkes RI.

[5] Cipolle, R.J., Strand, L.M., \& Morley, P.C., 1998. Pharmaceutical Care Practice : The Clinician's Guide, 2nd Edition. USA: McGraw-Hill Companies,Inc.

[6] Alkahel, A. 2011. Al-Quran's the Healing (Edisi 2). Jakarta: Tarbawi Press

[7] Anwar, K.K., Hadju, V., Massi, M.N., 2019. Pengaruh Murottal Al-Quran terhadap Peningkatan Kadar Beta-endorphin dan Penurunan Tingkat Nyeri Pasien Post Sectio Caesarea. J. Kesehat. 10, 58-6

[8] Farah, B., Germano-Soares, A., Rodrigues, S., Santos, C., Barbosa, S., Vianna, L., Cornelissen, V., Ritti-Dias, R., 2017. Acute and Chronic Effects of Isometric Handgrip Exercise on Cardiovascular Variables in Hypertensive Patients: A Systematic Review. Sports 5 , 55. https://doi.org/10.3390/sports5030055

[9] Mansouri, A., Vahed, A.S., Sabouri, A.R., Lakzaei, H., Arbabisarjou, A., 2017. Investigating Aid Effect of Holy Quran Sound on Blood Pressure, Pulse, Respiration and O. Ijss. https://doi.org/10.17359

[10] Jenie IM, Noor NM., 2010. Family history of hypertension is associated with exaggerated cardiovascular reactivity to mental but not to physical test. Med J Indones; 19: 118-123

[11] Mustamir. 2009. Potensi SQ,EQ, dan IQ di balik Ayat-Ayat Al-Fatihaah (Edisi 1). Yogyakarta: Diva Press
[12] Hamer, M., Malan, L., 2010. Psychophysiological Risk Markers Of Cardiovascular Disease. Neurosci.Biobehav. Rev. 35, 76-83. https://doi.org/10.1016/j.neubiorev.2009.11.004

[13] Kupper, Denolle, 2015. Cardiovascular Reactivity to Mental Stress and Mortality in Patients With Heart Failure. E E V E R INC VOL. 3, NO. 5, 2015. https://doi.org/h t t p : / / x . d o i.org/ 10.101 $6 / \mathrm{j} . \mathrm{j}$ c h f. 2014.12

[14] Alligood, M. R. 2014. Nursing Theories \& Their Work, 8th Edition. Missouri: Mosby Elsevier

[15] Herdiman, H., Ilbert, R., 2019. The Effect of Murottal and Music Therapy on Reducing Blood Pressure in Palimanan Climbon. KnE Life Sci. https://doi.org/10.18502/kls.v4i13.5341

[16] Sherwood, L. 2011. Fundamentals of Human Physiology. 4th ed. USA: Brooks/Cole

[17] Ariyadi, R., Santoso, B., Saha, D., 2018. The Effect Of Supportive Religious Audio On Hemodynamic Status Of Community Health Nursing. https://E.Journal.Unair.Ac.Id//jchn International Journal Of Multidisciplinary Education And Research. www.educationjournal

[18] Irmachatshalihah, R., Armiyati, Y., 2019. Murottal Therapy Lowers Blood Pressure in Hypertensive Patients. Media Keperawatan Indones. 2, 97. https://doi.org/10.26714/mki.2.3.2019.97-104

[19] Nasiri, A.A., Shahdadi, H., Mansouri, A., 2017. An Investigation into the Effect of Listening to the Voice of the Holy Quran on Vital Signs and Consciousness Level of Patients Admitted to the ICU Wards of Zabol University of Medical Sciences Hospitals. World Fam. Med. JournalMiddle East J. Fam. Med. 15 , 75-79. https://doi.org/10.5742/MEWFM.2017.93142 